\title{
BEYOND THE WALLS: OUTREACH INITIATIVES IN LIBRARY, UNIVERSITY OF MORATUWA
}

\author{
Ruvini C. Kodikara \\ Library, University of Moratuwa \\ ruvinik@lib.mrt.ac.lk \\ Thushari M. Seneviratne * \\ Library, University of Moratuwa \\ thushari@lib.mrt.ac.lk \\ C.N.D. Punchihewa \\ Library, University of Moratuwa \\ nishan@lib.mrt.ac.lk
}

\begin{abstract}
Outreach librarianship - a concept which had a history of more than 40 years - has been diversely used in libraries all over the world as well as in Sri Lanka. Outreach Librarianship is aimed to reach out to traditional and non-traditional library users, extending beyond the walls of a physical library to serve underprivileged communities. Establishment of Outreach Services Division in Library, University of Moratuwa has fulfilled a longfelt need to serve the community living in the vicinity of University of Moratuwa. "Child Development Programme" at Sumudu Preschool located in the University premises and "Reading Camp" at Bodhiraja Vidyalaya, Katubedda, Moratuwa are two outreach initiatives that the staff of Library, University of Moratuwa are currently engaged in. This paper describes the accomplishment of these two outreach initiatives through management of physical and human resources without an outreach budget.
\end{abstract}

Keywords: Academic Libraries, Outreach Librarianship, Libraries and Community, Library Staff 


\section{Introduction}

Outreach can be described as the process of engagement with the individuals and organizations by entities or individuals. The purpose of outreach is to serve underprivileged communities and disadvantaged groups. Outreach is a two-way engagement. It builds sustainable, mutually beneficial relationships, though it does not produce immediate outcomes.

Outreach in libraries is not a newly built concept but it extends roots to more than 40 years. In 1984, W.J. Martin wrote "Outreach has had some influence upon library affairs during the past ten to fifteen years." "Service to the disadvantaged", "service to special groups", "extension activities", "service to the un-served", "community librarianship" and "beyond the traditional library" are some phrases associated with this concept.

Lipsman (1972) defined outreach as "activities or programmes undertaken in addition to or in place of ordinary library services with the intention of reaching a disadvantaged population". After 40 years, Dennis (2012), defined outreach as "reaching out to non-traditional library users, extending beyond borders of a physical library and promoting under-utilized or new library resources". According to Online Dictionary of Library and Information Science (ODLIS) (Reitz, n.d.), outreach has been described as "library programs and services designed to meet the information needs of users who are un-served or underserved, for example, those who are visually impaired, homebound, institutionalized, not fluent in the national language, illiterate, or marginalized in some other ways."

Therefore, outreach can be described as a twofold concept with action and symbolism. "The action involves reaching outside the library into deprived or minority communities, to people who are information poor and lacking material resources. The symbolism entails rejection of traditional library notions of neutrality in name of social justice" (Martin, 1984).

Outreach goes hand in hand with library marketing, promotions, public relations, special events, social responsibility, user education, academic collaboration, etc. The Association of Library Communications \& Outreach Professionals (ALCOP) located in New Jersey, USA is a body which ties marketing, public relations, special events, fundraising, outreach, and program development professionals for public and academic libraries. According to the vision statement of ALCOP "public relations, community outreach and marketing professionals of libraries today, have to strive to remain competitive by using innovative tools for effective marketing" ("The Association of Library Communications \& Outreach Professionals," n.d.).

Sri Lankan libraries and information services conduct outreach activities as the libraries all over the world. National bodies such as Sri Lanka Library Association, National Library and Documentation Services Board, and National Institute of Library and Information Science have been engaged in outreach activities with other libraries in the island. Although outreach activities have part and parcel roles with libraries and information services in Sri Lanka, none 
of the titles include "outreach librarian" nor do the divisions dedicate to outreach activities. Hence, establishment of Outreach Services Division at Library, University of Moratuwa (UoM) is a significant milestone in the history of library and information services in Sri Lanka.

\section{Literature Review}

Today, many libraries have initiated different strategies as outreach activities to promote the services of libraries and to reach new users. By implementing successful outreach initiatives, libraries gain many opportunities to measure their value to the parent organization.

In "NILIS Informer" the official newsletter of National Institute of Library and Information Science (NILIS), University of Colombo, Sri Lanka has highlighted some of the outreach activities of its staff and students. They have engaged in a 'Community development project' at the Shasthrodaya Pirivena Library, Marapana, Sri Lanka. NILIS group has used their knowledge and skills to organize the collection in this library. And, NILIS has conducted different outreach programmes to enhance knowledge and skills of school children and teachers. A training programme on 'action research methodology' was conducted for primary school teachers in Western Province at the Boralesgamuwa Maha Vidyalaya. Improving the writing skills of the school educational professionals was the objective of the "workshop on creative writing' that was held in Hali-ela educational centre (Outreach activities around the country, 2013).

Dennis (2012) has conducted a survey to compare outreach initiatives by academic librarians in the US. The survey has revealed that librarians have offered a significant impact on their learning communities by their outreach activities. According to Jesudason (1993), collaboration between schools and academic libraries through joint programmes is essential to minimize the repetition of works and waste of human resources. In his paper, Jesudason (1993) explains as to how these joint programmes can be initiated between schools and universities. As he continues, supportive infrastructure available to public school teachers and principals when coordinating activities with university and the library, was the critical factor that affects the success rate of outreach activities.

According to Davis-Kahl (2004), the School Partnerships in Research and Information Technology (SPIRIT) programme was one of the successful outreach proposals at University of California Irvine (UCI) libraries. She has mentioned goals of the programmes:

- To teach information literacy skills to high school students,

- To increase students' understanding and confidence in their ability to locate and use information appropriately,

- To facilitate students and teachers to access and use of scholarly electronic resources, and

- To assist students to become eligible and competitive to get enrolled at the University of California. 
Davis-Kahl (2004) has further mentioned that staff from UCI libraries visited teachers and librarians at the schools to gather information on views and goals of teachers to plan on how school libraries can be developed using its existing resources.

Community outreach can be defined as a strategic combination of resources and talents. It includes a diverse set of activities encompassing research, education and delivery of resources in a defined (geographically, economically, medically) set of the population (Basler, 2005). In a study of introducing outreach partnerships, Basler (2005) describes the community outreach projects at Medical University of South Carolina which target largely rural and minority populations. For example, Enterprise Community Programme was developed to address community problems in environmental health, and information was provided via computers in community centers, schools, churches and public libraries. Also, Healthy Southern Carolina Gateway programme served to provide access to electronic health information for public libraries.

According to Huber et al. (2011), time constraints or commitments, staffing, scheduling and absenteeism, inadequate space, and issues associated with technology were the barriers in conducting outreach activities.Lack of proper funding sources creates many barriers for these outreach activities. Nelson (2007) from University of Purdue has conducted a survey to identify libraries' outreach activities to improve reference services. In his study, $74 \%$ of respondents had indicated that there was no change in the budget allocation for outreach activities during last five years. Gluibizzi (2009) discusses the techniques with low-cost and high impact for outreach initiatives at Fine Arts Library, University of Ohio State.

Modern advanced technology has a direct influence on many library outreach activities.Adeyemon (2009) from University of Case Western Reserve used outreach services to bridge technology and training gaps. He described how outreach services could be used for students who had limited opportunity in information and digital literacy skills training. Fabian, D'aniello, Tysick and Morin (2003) explain how multimedia technologies were used to deliver variety of outreach events over a calendar year at University of Buffalo libraries. After conducting an analysis using Facebook to build relationships with students, Phillips (2011) suggests to libraries to apply their knowledge in modern technologies when initiating outreach activities. Similar study employed by Ayu and Abrizah (2011) to explore the use and application of Facebook among Malaysian academic libraries, proves to provide better practices using social networking sites. This aims for librarians to communicate effectively with their users.

Carter and Seaman (2011) conducted an exploratory survey inquiring the libraries' dedicated outreach positions, outreach committees, mission statements, staff time and financial resources allocated to outreach and libraries' future plans for outreach. Also, they explain about libraries' reasons for supporting outreach activities, which are; (1) reaching out to their users, (2) encouraging use of library and (3) promoting a positive image on the university within the community. 
Literature on outreach highlights that many universities and libraries have appointed dedicated personnel and departments for outreach activities. Department of Education and Outreach $(\mathrm{E} \& \mathrm{O})$ at the University of California Irvine libraries was established to address growing needs in library education and outreach initiatives (Davis-Kahl, 2004). Dennis (2010) insists on creating a position called 'outreach librarian' to oversee and correlate existing efforts of outreach activities at University of Mississippi libraries. Later, the Dean of libraries at University of Mississippi appointed a new committee chaired by the outreach librarian to help, create and implement library outreach goals.

\section{Establishment of Outreach Services Division, Library University of Moratuwa}

University of Moratuwa Library (UML) is one of the most prominent technological libraries in the country. Its main subject specializations are Engineering, Architecture and Information Technology. University of Moratuwa Library has excelled in providing knowledge services within the university and between other institutions in Sri Lanka. Having recognized the social responsibility in reaching the community around the university premises, the library pioneered to establish Outreach Services Division (OSD) in September 2013 under the patronage of Library Committee with the approval of the University Senate. To address the changing nature of library services which are no longer limited to a particular space in a building with stack of books, following objectives were laid down:

- To create awareness on the services of UML beyond its physical boundaries,

- To build a rapport with neighborhood so that the library becomes a central institution,

- To provide expertise and human resources to improve the knowledge culture of the community, and

- To provide reference facilities to the community concerned.

UML is a knowledge hub filled with physical resources, human resources and technology that others may not have the access to. These could be shared on voluntary basis for a common good among following target groups:

- Preschools (University Day Care Centre)

- Schools and public libraries

- Research institutes

- Other government institutions

In the beginning of the project, institutions in areas of Piliyandala, Moratuwa and Ratmalana were considered. According to the initial proposal, types of services as following could be offered:

- Story telling for preschool/school children

- Library tours

- Delivering lectures on information literacy skills 
- Training library staff.

Similar to libraries all over the world, UML did not receive additional funds for doing outreach activities. Therefore, the situation called for a SWOT analysis with respect to using library resources - physical as well as human - to fulfill stipulated outreach activities. Table 1 presents the SWOT analysis in relation to the situation.

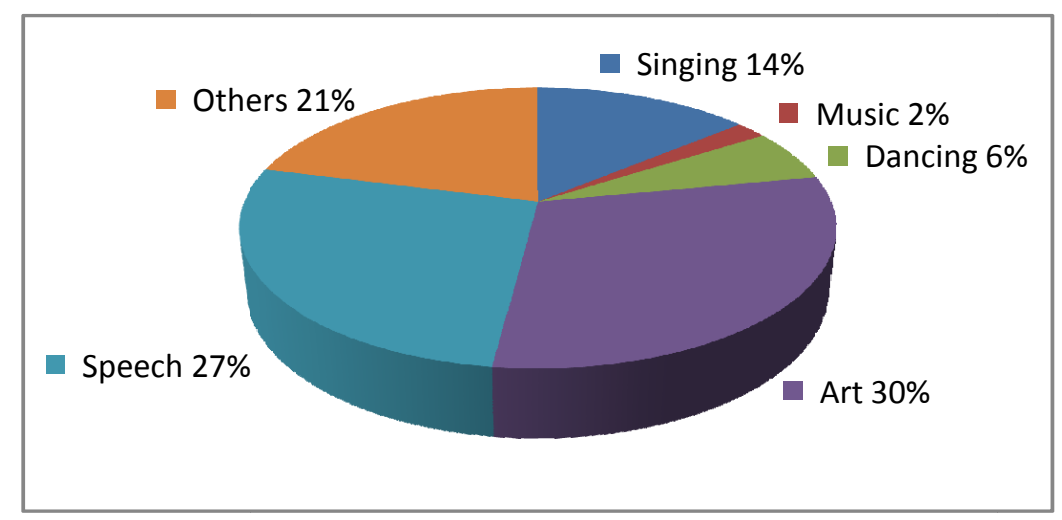

Figure 1: Analysis of Talents

In addition to the SWOT analysis, a survey was carried out among library staff members to get an idea about the soft skills they possess. Talents in singing, dancing, music, speech and drama, oratory were investigated through a questionnaire survey. Out of forty six (46) library staff members, 33 members responded. Fourteen members have at least one talent of the list. Ten members have 2-3 talents, and two members are having five (05) talents listed. Figure 1 depicts the percentage of talents. 


\section{Strengths}

- Dedicated skillful staff

- Regular communication between library divisions, staff and management

- Capable staff

- Private fund raising initiatives have been encouraged

- Support from university

- Excellent programs, services and materials for the community

- Library collections - not limited to curriculum - cater to reach broad range of ages

- Good investment in technology

- Computer training lab

- Well designed, maintained website

- Provision of Internet/Wi-Fi to users

- Online links to top titles and reading lists

- 24/7 access to catalog and databases

\section{Weaknesses}

- Facilities that cannot be easily accessed by the community

- Current library hours of operation can prevent community in accessing library services

- Not known as a community center

- Insufficient staffing specially for ICT enabled services

- Some times staff can be inflexible

- Insufficient time for outreach activities

- Limited funding

- Need for additional equipment

- Limited and inconsistent efforts and strategies in marketing

- Lack of communication with community
Opportunities

- Provide a public place for community

- $\quad$ Space utilization for community needs

- Staff training and empowerment

- Provide cross-training for staff

- Build positive staff attitudes

- Involvement of volunteers

- Building rapport with support organizations

- Image of the Library will be increased among the community as well as in the university.

- Can become leading advisor for information literacy

- Expand marketsfor new libraryservices

- Increasing demand for services

\section{Threats}

- Occasional disruptive behavior of community

- Misunderstanding between library staff and community

- Minimum interest in extra curricular activities

- Treat assistance as a burden and interruption to their daily life 
due to both community growth

and economic downturn

- Increased outreach to community

- Increase library user base

\section{Outreach Activities}

In parallel with skill-survey, outreach staff, under the guidance of the librarian, selected two institutions to conduct their outreach activities at the initial stage. The two target groups were:

- Kids of Sumudu PreSchool, University of Moratuwa,

- Students of Bodhiraja Vidyalaya, Katubedda, Moratuwa

Librarian and representatives paid visits to these two institutions and discussed about the outreach initiative commenced at UML. Lengthy discussions were carried out with all stakeholders to seek how library staff could be integrated with their target groups. With the results of requirement analysis and skills survey, OSD came up with two projects:

- Child Development Programme for kids of Sumudu PreSchool, University of Moratuwa, and

- Reading Camp for students of Bodhiraja Vidyalaya, Katubedda, Moratuwa. 


\section{Child Development Programme}

Sports and Welfare Association of University of Moratuwa runs the Sumudu Preschool and Day-Care Centre at University of Moratuwa. There are eighteen (18) kids currently following their education in Sumudu Preschool and two (02) preschool teachers are educating them.

In collaboration with these preschool teachers and office-bearers of Sports and Welfare Association of University of Moratuwa, UML launched "Child Development Programme" on $17^{\text {th }}$ September 2013. Main objective of this programme were:

- To fulfill educational needs of preschool children using modern technology,

- To enhance skills and talents of preschool children, and

- To entertain preschool children.

Child development programme is conducted every Tuesdays and Fridays at the preschool by members of library staff. Table 2 presents the activities carried out in September and October, 2013.

Table 2: Activities of Child Development Programme

\begin{tabular}{|c|c|c|}
\hline Date & Activity & Description \\
\hline $\begin{array}{l}17^{\text {th }} \\
\text { September }\end{array}$ & Language Learning & $\begin{array}{l}\text { Language learning is aimed to help the kids } \\
\text { to recognize, read, and write letters of the } \\
\text { Sinhala and English alphabet (Ongoing } \\
\text { activity). }\end{array}$ \\
\hline $\begin{array}{l}24^{\text {th }} \\
\text { September }\end{array}$ & Wonders of Colours & $\begin{array}{l}\text { Learning about colour is an important part of } \\
\text { a child's preschool development. Colours } \\
\text { and colouring techniques were introduced to } \\
\text { kids. (Ongoing activity). }\end{array}$ \\
\hline $\begin{array}{l}27^{\text {th }} \\
\text { September }\end{array}$ & Clay World & $\begin{array}{l}\text { To improve motor skills, creativity and } \\
\text { logic, kids were motivated to make clay } \\
\text { sculptures (Ongoing activity). }\end{array}$ \\
\hline $1^{\text {st }}$ October & $\begin{array}{l}\text { Universal Children's' } \\
\text { Day }\end{array}$ & $\begin{array}{l}\text { Pre-Childhood Development Programme } \\
\text { was conducted to celebrate the Universal } \\
\text { Children's Day This special programme was } \\
\text { based on the ambitions and titled as } \\
\text { "AdathApei, HetathApei". }\end{array}$ \\
\hline
\end{tabular}


$11^{\text {th }}$ October Once upon a Time... Through storytelling, kids are given an opportunity to experience exciting journeys into the unknown places, people and things (Ongoing activity).

25th October Go on the Stage "Dompeta yana parakoibado" is a famous folk-drama in Sri Lanka. To entertain as well as to educate the kids on folk-lore, Library staff performed folk-drama.

\section{Reading Camp}

Bodhiraja Vidyalaya, Katibedda, Moratuwa - a primary school located near University of Moratuwa. There are roughly seventy (70) children studying in this primary school, where eight (08) teachers serve. This school caters to underprivileged community in its vicinity. School library which functioned sometimes back had been closed due to lack of staff. Therefore, library launched "Reading Camp" on $9^{\text {th }}$ October 2013. Main objectives of the Reading Camp are:

- To inculcate reading habit among school children,

- To teach information literacy skills, and

- To support educational activities using modern technology.

Reading Camp is conducted every Wednesday at Bodhiraja Vidyalaya by members of UML. Table 3 presents the activities carried out in October 2013.

Table 3: Activities of Reading Camp

\begin{tabular}{ccc}
\hline Date & Activity & \multicolumn{1}{c}{ Description } \\
\hline $9^{\text {th }}$ October & Back to the Library & $\begin{array}{l}\text { Awareness programme was conducted to educate } \\
\text { the students about the proper use of library and } \\
\text { highlighted the importance of reading. }\end{array}$
\end{tabular}

To re-open the school library in Bodhiraja Vidyalaya, a library book will be issued to every child on Wednesdays in collaboration with school teachers. Children will be asked to do an activity, based on the burrowed book in aligning with "Empowering 8" information literacy model.

$9^{\text {th }}$ October Animals around us An activity based programme on Animals for
students of Grade land 2 on was conducted. 


\begin{tabular}{lll}
\hline & & $\begin{array}{l}\text { Poems, songs and stories used in this programme } \\
\text { entertained the children as well as provided facts } \\
\text { and figures about the animals around us. }\end{array}$ \\
\hline $23^{\text {rd }}$ October & $\begin{array}{l}\text { Language Learning } \\
\text { with Colours }\end{array}$ & $\begin{array}{l}\text { In collaboration with school teachers, language } \\
\text { learning activities were carried out for students of } \\
\text { Grade } 1 \text { and } 2 \text { using colours. Pictures and poems } \\
\text { are also introduced in parallel. (ongoing activity) }\end{array}$ \\
\hline $23^{\text {rd }}$ October & Stamp World & $\begin{array}{l}\text { A Session on stamp collecting - one of the } \\
\text { world's most popular hobbies - for students of }\end{array}$ \\
& & $\begin{array}{l}\text { Grade 3, } 4 \text { and 5. Along with the history and } \\
\text { practices of stamp collecting, there was a a } \\
\text { demonstration on "How to make a stamp album" } \\
\text { to encourage students. }\end{array}$ \\
\hline $30^{\text {th }}$ October & Beyond the Sky & $\begin{array}{l}\text { Through videos, poems and demonstrations, } \\
\text { Grade 3, 4 and 5 students were given an } \\
\text { opportunity to experience the facts about the sky } \\
\text { and beyond the sky. At the end of the programme } \\
\text { a quiz was held. }\end{array}$ \\
\hline
\end{tabular}

\section{Participation of Library Staff}

Irrespective of the worker categories, divisions they are allocated, staff of UML have participated in outreach programme and shown keen interest in its success. In collaboration with teachers, the programme or activity is organized by the Outreach Services Division. Then responsibility of a programme or activity is assigned to a library staff member(s) in advance. The selection is based on their skills, abilities, expertise and willingness to conduct. They willingly take part in planning process, and discussions are continued in the Outreach Services Division. Information Technology Division of the Library has been always integrating with those activities. To promote the activities as well as staff participation, web pages http://www.lib.mrt.ac.lk/index.php/child-development-programme and http://www.lib.mrt.ac.lk/index.php/reading-camp are maintained. Further, these programmes are promoted via social networks such as Facebook. At the end of each and every activity, a review is carried out with all the stakeholders since reflective practice will promote future activities.

Attending to daily routine work of the library, especially secluded to one place, participating in outreach activities was a complete breakaway from the monotonous work for the staff. The enthusiasm shown by each library personnel, despite the post, has brought out the individual hidden talents that may not be taken into any consideration in a library or any office. Most importantly, their participation has not hindered any services in the library. The co- relation between staff in different sections, sharing- ideas, team work have bonded the mutual relations and brotherhood among staff. This has brought a live atmosphere in the library itself as staff discusses and enjoys the output of each person. 


\section{Concluding Remarks}

Need of the hour was genuinely felt when the staff of Outreach Services Division visited the library of Bodhiraja Vidyalaya, whose collection is enriched with many story books in Sinhala and English, though it was kept closed, and trees and grass encroached onto the building. Due to lack of staff and children who did not know the importance of vast information hidden in celluloid pages, had no guidance whatsoever to visit the library. Economic status of parents and daily needs of children, the home environment barred many children in the area from obtaining education. In this background, school library is not playing a part and parcel role in their lives. To improve their reading habits, to bring the importance of attending the school, to improve social harmony, the gap has to be bridged between the university and the school.

Outreach activities of UML are still at the inception and have to travel many more miles to reach its goals. Dedication and enthusiasm of staff and integration of staff with village inhabitants and community is essential in achieving the goals. Making a child walking through the gates of the university would be the ultimate goal of the outreach activity.

Eminent Vincent E. Guiliano in Manifesto for librarians wrote "libraries are not connected in any important way to the most important priorities of either individuals or society" (Martin, 1984). If outreach librarianship continues to consist of series of isolated special initiatives, outreach activities remain as there as forty years ago. Hence outreach activities have to be integrated with common vision, mission of the library as well as the institution.

\section{References}

Adeyemon, E. (2009). Integrating Digital Literacies into Outreach Services for Underserved Youth Populations. The Reference Librarian, 50(1), 85-98. doi:10.1080/02763870802546423

Association of Library Communications \& Outreach Professionals, The. (n.d.). ALCOP. Retrieved from: http://alcop.org/about-2/

Ayu, A. R. R., \& Abrizah, A. (2011). Do you Facebook? Usage and applications of Facebook page among academic libraries in Malaysia. The International Information \& Library Review, 43(4), 239-249. doi:10.1016/j.iilr.2011.10.005

Basler, T. G. (2005). Community outreach partnerships. Reference Services Review, 33(1), 31-37. doi:10.1108/00907320410519441

Carter, T. M., \& Seaman, P. (2011). The Management and support of outreach in academic libraries. Reference \& User Services Quarterly, 51(2), 163-171. doi:10.5860/rusq. $5 \ln 2.163$ 
Davis-Kahl, S. (2004). Teaching, Learning and Research: Linking High School Teachers to Information Literacy. Research Services Review: RSR, 31(4), 313-319.

Dennis, M. (2010). Creating an outreach librarian at the University of Mississippi. Mississippi Libraries, 74(2), 31-33.

Dennis, M. (2012). Outreach initiatives in academic libraries, 2009-2011. Reference Services Review, 40(3), 368-383. doi:10.1108/00907321211254643

Fabian, C. A., D'aniello, C., Tysick, C., \& Morin, M. (2003). Multiple Models for Library Outreach Initiatives. The Reference Librarian, 39(82), 39-55. doi:10.1300/J120v39n82_04

Gluibizzi, A. K. (2009). The world of outreach: One art librarian's perspective. Library Review, 58(2), 116-123. doi:10.1108/00242530910936934

Huber, J. T., Kean, E. B., Fitzgerald, P. D., Altman, T. A., Young, Z. G., Dupin, K. M., ... Holst, R. (2011). Outreach impact study: the case of the Greater Midwest Region. Journal of the Medical Library Association: JMLA, 99(4), 297-303. doi:10.3163/1536-5050.99.4.007

Jesudason, M. (1993). Academic libraries and outreach services through precollege programs: A proactive collaboration. Reference Services Review, 21(4), 29-96. doi:10.1108/eb049198

Lipsman, C. K. (1972). The Disadvantaged and Library Effectiveness. American Library Association.

Martin, W. J. (1984). Outreach. Library Review, 33(1), 22-28. doi:10.1108/eb012761

Nelson, M. S. (2007). Initiating engineering outreach reference services: background and practice. Reference Services Review, 35(2), 265-284. doi:10.1108/00907320710749182

Outreach activities around the country. (2013, September). NILIS Informer. 1(1), p.3. Retrieved from: http://nilis.cmb.ac.lk/images/Newsletter/NILIS_Informer_Web.pdf

Phillips, N. K. (2011). Academic Library Use of Facebook: Building Relationships with Students. The Journal of Academic Librarianship, 37(6), 512-522. doi:10.1016/j.acalib.2011.07.008

Reitz, J. M. (n.d.). ODLIS : Online Dictionary for Library and Information Science. Retrieved from http://www.abc-clio.com/ODLIS/odlis_A.aspx 